American Journal of Environmental Sciences 7 (1): 26-34, 2011

ISSN 1553-345X

(C) 2010 Science Publications

\title{
Physical Composition, Nutrients and Contaminants of Typical Waste Dumping Sites
}

\author{
${ }^{1} \mathrm{H}$. Meuser, ${ }^{2}$ K.S. Grewal, \\ ${ }^{1}$ R. Anlauf, ${ }^{2}$ R.S. Malik, ${ }^{3}$ R.K. Narwal and ${ }^{4}$ Jagmohan Saini \\ ${ }^{1}$ Osnabrueck University of Applied Sciences, \\ PO Box 1940, 49009 Osnabrueck Germany \\ ${ }^{2}$ Department of Soil Science CCS Haryana, Agricultural University, \\ Hisar 125004, India \\ ${ }^{3}$ Department of Economic and Statistical Analysis, Government of Haryana, Fatehabad, India \\ ${ }^{4}$ Assist. Manager, Chambal Fertilizers and Chemicals Ltd., Shri Ganganagar (Rajasthan), India
}

\begin{abstract}
Problem statement: The composition of wastes is quite variable depending upon the generating source and mode of collection. Most of the material from the domestic activities will be organic in nature and contains essential plant nutrients, whereas the dumping material of commercial and industrial wastes usually contains appreciable amounts of heavy and potentially toxic metals and organic pollutants. Approach: Objective of the present study was to characterize the physico-chemical properties of the waste material and the distribution and extent of toxic pollutants in three selected typical dumping sites in the state of Haryana, India. Results: $62-65 \%$ of the waste fine material consisted of mineral particles and biodegradable organic waste, 20-25\% consisted of construction and demolition waste and the remaining $10-15 \%$ were other materials such as study, plastic, metals, glass and timber, with an amount of polyethene of 3.4-5.7\%. The ratio of the plant available concentrations of $\mathrm{P}, \mathrm{K}$ and $\mathrm{S}$ and their total amounts were $3-7 \%$ for $\mathrm{P}$ and $1-4 \%$ for $\mathrm{S}$, whereas the macronutrient potassium reached values of $29-39 \%$. Metals $\mathrm{As}, \mathrm{Ba}, \mathrm{Cd}, \mathrm{Cr}, \mathrm{Cu}, \mathrm{Ni}, \mathrm{Pb}$ and $\mathrm{Zn}$ were present in all samples (total concentration in aqua regia extract). As, $\mathrm{Ba}, \mathrm{Ni}$ and $\mathrm{Pb}$ did not show clear differences between the three investigates sites. $\mathrm{Cd}, \mathrm{Cr}$ and $\mathrm{Zn}$ concentrations were high but different at the different sites (Cu maximum: 1,964 mg kg${ }^{-1}$, Zn maximum: 2,200 $\mathrm{mg} \mathrm{kg}^{-1}$ ). The mobility of the metals was calculated as the ratio of DTPA/aqua regia extraction. Cd showed the highest ratio (18-22\%), while the other calculated metals showed much lower ratios $(\mathrm{Cu}$ 6.7, Pb $7.9 \mathrm{Ni} 2.1$, Zn 3.6 and $\mathrm{Cr}$ $0.5 \%)$. In general, PAH and benzo(a)pyrene concentrations fell below the detection limit. Also the phenol index did not exceed the detection limit of $1.2 \mathrm{mg} \mathrm{kg}^{-1}$ (with two exceptions). In 14 out of 36 samples a GC-MS screening was conducted in order to get an overview of the organic pollutants usually present in the dumpsites. In all cases there was no relevant amount of organic pollutants that would be capable of measurement. Conclusion: The dumping sites are plant nutrient deposits, particularly for $\mathrm{K}$, which could be used in future in a line with ideas of urban mining. The use of the waste material for fertilizing purposes may be restricted due to the metal contaminant concentrations. The analyzed organic pollutants did not indicate problematical concentrations.
\end{abstract}

Key words: Heavy metals, organic pollutants, plant nutrients, aqua regia extract, DTPA extract, Electrical Conductivity (EC), composting technology, potentially toxic, dumping material, recycling activities, leachate runoff

\section{INTRODUCTION}

With increasing regulatory pressure prohibiting ocean-based disposal of wastes and effluents, there is an increasing tendency to dispose wastes in landfill sites. Such disposals are the preferred option in India as well as in many other countries of the world. In India the waste disposal can be assessed as problematical.
The possible reasons are low collection capacity, lack of landfill management, reduced recycling activities, waste dispersion through livestock, a low awareness with respect to waste problems and absence of garbage incineration or only restricted to private companies, hotels and hospitals and a low level of composting technology. 
The raw waste in India is generally a mixture of domestic, commercial and industrial activities. The composition of these wastes (solid as well as effluents or leachates from them) is quite variable depending upon the generating source, mode of collection and treatment provided. Most of the material which comes from the domestic activities (e.g., plant residues, weeds, household garbage, sewage sludge) will be organic in nature and contains essential plant nutrients. The dumping material of commercial and industrial wastes (like plastic bags, tires of automobiles, lead batteries, parts of electronic equipments), however, contain appreciable amounts of heavy and potentially toxic metals such as $\mathrm{As}, \mathrm{Cd}, \mathrm{Cr}, \mathrm{Hg}, \mathrm{Ni}$ and $\mathrm{Pb}$ and organic pollutants. Their continuous dumping on surface land may result in an accumulation in the soil in the vicinity of the dumping site. The leachate runoff from these sites during rainy seasons further aggravates this problem to the surrounding areas.

Apart from the environmental pollution, there is a possibility that pollutants from city dumping sites may contaminate the underground water or may be absorbed by plants growing in the nearby agricultural fields and may thus create human and animal health problems. It has also been observed that the leachate of these dumping sites sometimes accumulates in the low-lying areas (Williams, 2005; Meuser, 2010).

Management of city solid waste in the State of Haryana, India, was found deplorable and the people's perceptions about solid waste varied, depending on their life style, food habits, region, religion, seasons. The wastes generated were dumped in a variety of places mainly in open areas of the localities. It is collected on each day or alternate day and then transported to the dumping sites by means of various modes managed by municipal committees and/or through contractual basis. Overall, the dumping sites are not properly guarded and well maintained, resulting into an easy accessibility by stray animals. Municipal solid wastes generally comprise of rotten food and household articles, tree branches, papers, paints, sewage sludge, plastic and bricks/rubbles. Though composition of solid wastes generated in the cities needs to be studied, plastic is a great nuisance amongst the various components of municipal waste and is growing at an alarming rate.

The exact data of the waste being generated in each city/town of concern was not available because of different reasons, such as:

- The waste collection is largely done on annual contract basis by the contractors and for the sake of ease their workers dump the collected wastes at nearby open fields or areas in and around the cities and the entire waste does not reach the dumping sites

- The waste collected is estimated in terms of vehicle carrying capacity/tractor trolleys coming to the dumping sites

- Data available on municipal solid waste management with municipalities is scarce

- information is not publicly available on websites of the municipalities

- Most of the officials and staff are reluctant to provide any information on the present practices of solid waste management

The literature is very meager with respect to the possible effects and composition of the solid waste in and around the city dumping sites. The present collaborative study was therefore planned with the objectives of the physico-chemical characterization of the waste material and the distribution and extent of toxic pollutants in selected dumping sites.

\section{MATERIALS AND METHODS}

Investigation sites: An extensive field survey was done at various waste disposal sites in Haryana to evaluate the general solid waste management procedure, present situation and nature and amount of waste being collected and deposited in and around the cities. For the present study various dumping sites were assessed by onsite observations and finally three waste dumping sites i.e., Rohtak, Jind and Karnal (Fig. 1) were selected on the basis of variability of the nature of dump being received. The waste deposits varied ranging from relatively fresh (3-4 years) deposits at Karnal (Fig. 2) to very old deposits (35-40 years) at Rohtak (Fig. 3). The Jind site (8-10 years) consisted largely of construction debris and household waste and presently is situated in the centre of the town (Fig. 4).

Collection of samples: For sampling, the sites were divided into three blocks of $>1,000 \mathrm{~m}^{-2}$ each and then samples were taken from surface $(0-1 \mathrm{~m})$ and subsurface $(1-2 \mathrm{~m})$ depths from approximately15 randomly selected places in each block using hand operated window augers. A composite sample $(1.0 \mathrm{~kg})$ of each block for each sampling depth was then made by quartering method. This way six waste samples were collected from each site. Bulk duplicate samples (around $20 \mathrm{~kg}$ each) were also taken from these sites for segregation purpose. The samples were immediately transported to the laboratory on the day of sampling. 
Am. J. Environ. Sci., 7 (1): 26-34, 2011

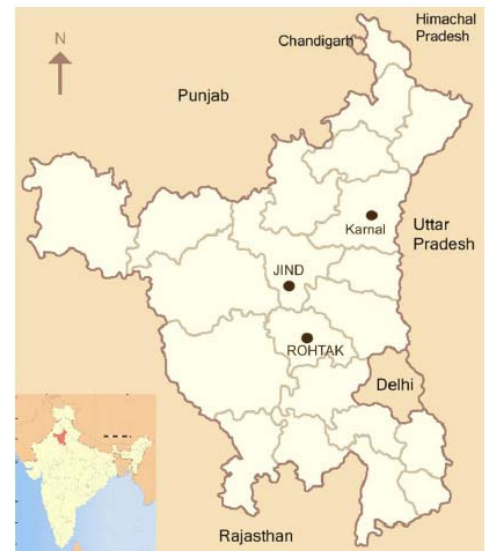

Fig. 1: Locations of the investigated dumping sites in the State of Haryana, India

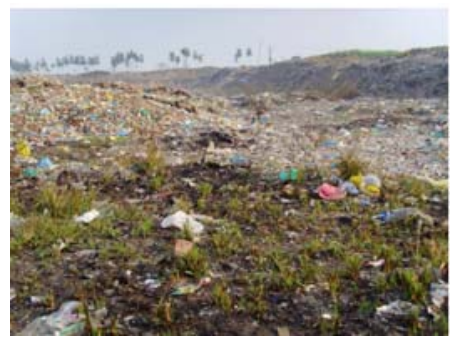

Fig. 2: Photograph of the dumping site at Karnal (Anlauf)

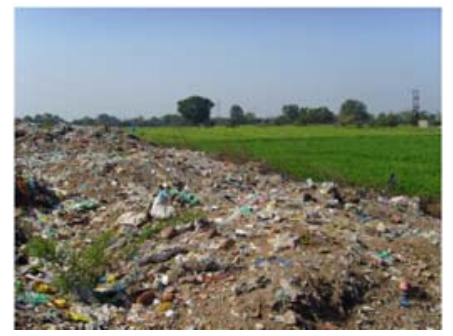

Fig. 3: Photograph of the dumping site at Rohtak (Anlauf)

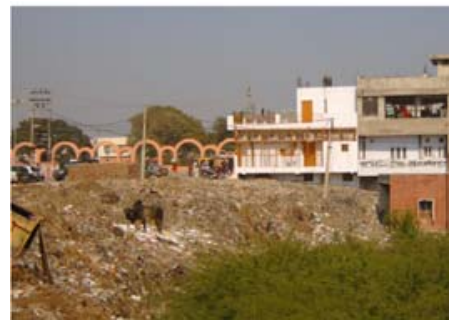

Fig. 4: Photograph of the dumping site in Jind; this dump is deposited in the centre of the city, at the back a hospital is visible (Meuser)
Table 1: Analytical methods

\begin{tabular}{ll}
\hline Parameter & Method \\
\hline Water content & $\begin{array}{l}\text { Gravimetric method (ISO 11465 : } \\
\text { 1993-12) }\end{array}$ \\
Texture & Piper (1966) (ISO 11277 : 2002-03) \\
Total Organic & Walkley and Black (1934) \\
Carbon (TOC) & (ISO 10694 : 1995-03) \\
pH value & Glass electrode method in CaCl 2 (1:5) \\
& (ISO 10390 : 2005-02) \\
Electrical & Conductivity bridge method in $\mathrm{H}_{2} \mathrm{O}$ (1:5) \\
Conductivity (EC) & (ISO 11265: 1996-10) \\
Total nitrogen & ISO 13878 : 1998-03 \\
Total phosphorus & Koenig and Johnson (1942) \\
Available phosphorus & Olsen (1954) \\
Total potassium & Page (1983) \\
Available potassium & Page (1983) \\
Total sulfur & Chesnin and Yien (1950) \\
Available Sulfur & Chesnin and Yien (1950) \\
Aqua regia extractable & EN 13657 : 2002-10, EN ISO \\
metals & $11885: 2009-05$ \\
DTPA extractable metals & Lindsay and Norvell (1978 ISO \\
& 14870 : 2001-12) \\
Polycyclic aromatic & Hein (1994) \\
hydrocarbons PAH-EPA) & \\
Phenol Index & ISO 6439: 1984-06 \\
\hline
\end{tabular}

Laboratory methods: The bulk samples were air-dried for several days and segregated manually for different composition fractions. The rest of the solid waste samples were also air-dried and separated into $<2$ and $>2 \mathrm{~mm}$ fractions. Both fractions were ground with the help of wooden pestle and mortar and finally stored in cloth bags for laboratory analysis. To analyze heavy metals the material was additionally ground by a ball mill. For laboratory analysis, internationally accepted and standardized analytical techniques were used. They are summarized in Table 1.

\section{RESULTS}

Physical composition of the waste samples: The bulk representative solid waste samples collected in duplicate from each site were manually segregated for different composition fractions and the data on dry weight basis are presented in Table 2. There was a variation with regards to the composition of the wastes among three experimental sites. A significant portion of Rohtak, Jind and Karnal municipal city solid waste forming approximately two-thirds was fine material consisting of both mineral particles and biodegradable organic waste, which included vegetables, food and horticultural waste. The second category contained construction and demolition waste, in first instance brick fragments. In Jind and Karnal approximately $25 \%$ of the total waste consisted of the rubble and in Rohtak it was about $20 \%$. The remaining category of waste like paper, plastic, metals, glass and timber constituted around $10-15 \%$. 
Am. J. Environ. Sci., 7 (1): 26-34, 2011

Table 2: Waste composition (\%) of the investigated sites at Rohtak, Jind and Karna

\begin{tabular}{lccc}
\hline Site & Rohtak & Jind & Karnal \\
\hline Fine earth (mineral and organic) (\%) & 65.1 & 65.6 & 61.8 \\
Construction rubble (\%) & 20.1 & 25.2 & 24.4 \\
Wood (\%) & 5.3 & 3.0 & 2.4 \\
Plastics (\%) & 5.7 & 3.4 & 5.0 \\
Glass (\%) & 1.2 & 1.1 & 0.8 \\
Metal (\%) & 0.2 & 0.4 & 0.2 \\
Paper (\%) & 0.1 & 0.4 & 1.1 \\
Textiles,Leather (\%) & 2.3 & 0.9 & 4.3 \\
\hline
\end{tabular}

Table 3: Total Organic Carbon (TOC), Total Nitrogen (TN), C/N ratio, $\mathrm{pH}$ value and Electrical Conductivity (EC) in Rohtak, Jind and Karnal dumping sites

\begin{tabular}{|c|c|c|c|c|c|c|}
\hline Location & Depth & $\begin{array}{l}\text { TOC } \\
(\%)\end{array}$ & $\begin{array}{l}\mathrm{TN} \\
(\%)\end{array}$ & $\begin{array}{l}\mathrm{C} / \mathrm{N} \\
\text { ratio }\end{array}$ & $\begin{array}{l}\mathrm{pH} \\
(\mathrm{CaCl} 2)\end{array}$ & $\begin{array}{l}\text { EC } \\
\left(\mathrm{dS} \mathrm{m}^{-1}\right)\end{array}$ \\
\hline \multicolumn{7}{|c|}{ Size fraction $>2 \mathrm{~mm}$} \\
\hline \multirow[t]{2}{*}{ Rohtak } & $0-1$ & 4.7 & 0.46 & 10 & 7.6 & 1.44 \\
\hline & $1-2$ & 3.9 & 0.36 & 11 & 7.6 & 2.11 \\
\hline \multirow[t]{2}{*}{ Jind } & $0-1$ & 5.4 & 0.48 & 11 & 7.5 & 0.95 \\
\hline & $1-2$ & 5.1 & 0.58 & 9 & 7.5 & 1.48 \\
\hline \multirow[t]{2}{*}{ Karnal } & $0-1$ & 4.5 & 0.52 & 9 & 7.5 & 1.85 \\
\hline & $1-2$ & 4.9 & 0.34 & 14 & 7.6 & 2.17 \\
\hline \multicolumn{7}{|c|}{ Size fraction $<2 \mathrm{~mm}$} \\
\hline \multirow[t]{2}{*}{ Rohtak } & $0-1$ & 3.9 & 0.34 & 11 & 7.6 & 1.12 \\
\hline & $1-2$ & 3.8 & 0.34 & 11 & 7.6 & 1.92 \\
\hline \multirow[t]{2}{*}{ Jind } & $0-1$ & 4.2 & 0.37 & 11 & 7.5 & 0.78 \\
\hline & $1-2$ & 4.2 & 0.42 & 10 & 7.5 & 1.39 \\
\hline \multirow[t]{2}{*}{ Karnal } & $0-1$ & 4.0 & 0.45 & 9 & 7.5 & 1.23 \\
\hline & $1-2$ & 4.5 & 0.36 & 13 & 7.6 & 1.67 \\
\hline
\end{tabular}

Among the non-biodegradable materials, plastics, in particular polyethene, was the highest fraction ranging from $3.4 \%$ in Jind to $5.7 \%$ in Rohtak samples. It was followed by glass (0.8-1.2\%) and then metal pieces (0.2-0.4\%). Wood and textiles including leather also constituted a sizable fraction of the total material with values ranging from 2.4-5.3 and 0.9-4.3\%, respectively. Maximum amount of recyclable and biodegradable paper was found in Karnal samples (1.1\%) in comparison to $0.2 \%$ in Rohtak and $0.4 \%$ in samples from Jind dumping site.

The moisture content of the waste samples on oven dry basis $\left(105^{\circ} \mathrm{C}, 48 \mathrm{~h}\right)$ varied from $14.3-26.1 \%$, highest content being in samples from Jind and Rohtak and the lowest in Karnal samples. The samples were generally dominated by sand sized material ranging from $82.9-88.3 \%$. The clay and silt sized material varied from 2.8-4.7 and from 8.8-12.5\%, respectively. In general, higher amount of clay and silt were observed in sub-surface (1-2m) samples than surface (0-1 m) samples, may be because of the leaching of finer material from upper horizons to lower ones with rain water percolation.
Table 4: Total (\%) and plant available (mg kg-1) phosphorus, potassium and sulfur content in Rohtak, Jind and Karnal for the size fraction $<2 \mathrm{~mm}$

\begin{tabular}{|c|c|c|c|}
\hline & $\mathrm{P}$ & K & $\mathrm{S}$ \\
\hline \multicolumn{4}{|c|}{ Total concentration (\%) } \\
\hline Rohtak mean & 0.68 & 0.74 & 1.36 \\
\hline range & $0.25-1.09$ & $0.52-1.09$ & $0.92-2.02$ \\
\hline Jind mean & 0.31 & 0.61 & 3.91 \\
\hline range & $0.25-0.38$ & $0.54-0.72$ & $0.37-4.09$ \\
\hline Karnal mean & 0.32 & 0.58 & 4.39 \\
\hline range & $0.25-0.47$ & $0.43-0.93$ & 2.81-4.69 \\
\hline \multicolumn{4}{|c|}{ Plant availableconcentration ( $\mathrm{mg} \mathrm{kg}^{-1}$ ) } \\
\hline Rohtak mean & 218 & 2,086 & 606 \\
\hline range & $136-383$ & $1,005-3,538$ & $294-960$ \\
\hline Jind mean & 209 & 1,969 & 443 \\
\hline range & 98-328 & $1,403-2,758$ & $290-618$ \\
\hline Karnal mean & 149 & 2,277 & 576 \\
\hline range & $84-227$ & $1,128-4,180$ & $384-1,112$ \\
\hline
\end{tabular}

Chemical properties of waste samples: The data on per cent organic carbon (TOC), the $\mathrm{pH}$ value as well as Electrical Conductivity (EC) for $>2$ and $<2 \mathrm{~mm}$ solid waste fractions are presented in Table 3 for all the three sites. The results indicated that all the samples showed variations irrespective of the size fraction $(>$ or $<2$ $\mathrm{mm}$ ). The average organic carbon content of the waste samples varied from $3.8-5.4 \%$. The variations in organic carbon content were not only observed from one site to another, but within the blocks from the same site indicating a large variation in the nature and type of the material being collected and deposited at these sites. Between the surface 5 layer $(0-1 \mathrm{~m})$ and the subsurface layer (1-2 m) no clear tendency was possible to detect. Due to the relatively high nitrogen content, the $\mathrm{C} / \mathrm{N}$ ratio exhibited values between 9 and 14 that can be considered as narrow and remembers on fertile agriculturally used soils.

With regards to the differentiation between the size fractions, similar trend of values of the electrical conductivity was also observed for all the experimental sites. Between the two analyzed soil depths, a tendency was visible indicating higher values in the second horizon. The average $\mathrm{pH}$ of all the samples was found near neutral at approx. 7.5 with low variation.

Total and plant available nutrients of the waste samples: Similar to the results presented in Table 3, a significant difference in nutrient concentrations between the two size fractions $>\mathrm{mm}$ and $<2 \mathrm{~mm}$ was not recognizable as well. In tendency, however, slightly lower magnitude of the nutrients was found in $<2 \mathrm{~mm}$ waste fraction samples. Accordingly, the following results refer to the fraction $<2 \mathrm{~mm}$, usually considered in soil analyses. The solid waste samples were analyzed for total and plant available nutrients phosphorus (P), potassium (K) and sulfur (S) using standard methods. 
Am. J. Environ. Sci., 7 (1): 26-34, 2011

Table 5: Aqua regia extractable metals (mg kg-1) in Rohtak, Jind and Karnal for the size fractions $>2 \mathrm{~mm}$ and $<2 \mathrm{~mm}$

\begin{tabular}{|c|c|c|c|c|c|c|c|c|}
\hline Site & $\begin{array}{l}\text { As } \\
\left(\mathrm{mg} \mathrm{kg}^{-1}\right)\end{array}$ & $\begin{array}{l}\mathrm{Ba} \\
\left(\mathrm{mg} \mathrm{kg}^{-1}\right)\end{array}$ & $\begin{array}{l}\mathrm{Cd} \\
\left(\mathrm{mg} \mathrm{kg}^{-1}\right)\end{array}$ & $\begin{array}{l}\mathrm{Cr} \\
\left(\mathrm{mg} \mathrm{kg}^{-1}\right)\end{array}$ & $\begin{array}{l}\mathrm{Cu} \\
\left(\mathrm{mg} \mathrm{kg}^{-1}\right)\end{array}$ & $\begin{array}{l}\mathrm{Ni} \\
\left(\mathrm{mg} \mathrm{kg}^{-1}\right)\end{array}$ & $\begin{array}{l}\mathrm{Pb} \\
\left(\mathrm{mg} \mathrm{kg}^{-1}\right)\end{array}$ & $\begin{array}{l}\mathrm{Zn} \\
\left(\mathrm{mg} \mathrm{kg}^{-1}\right)\end{array}$ \\
\hline \multicolumn{9}{|c|}{ Size fraction $>2 \mathrm{~mm}$} \\
\hline Rohtak mean & 5.3 & 318 & 1.4 & 70 & 179 & 35 & 186 & 382 \\
\hline range & $4.2-7.7$ & $260-640$ & $0.5-2.2$ & $51-85$ & $99-256$ & $29-49$ & $77-315$ & 208-614 \\
\hline Jind mean & 4.1 & 303 & 3.6 & 49 & 325 & 28 & 137 & 341 \\
\hline range & $3.6-4.5$ & $249-434$ & $0.5-7.9$ & $39-55$ & $50-971$ & $25-29$ & $48-234$ & $190-551$ \\
\hline Karnal mean & 4.5 & 284 & 1.0 & 128 & 680 & 43 & 155 & 789 \\
\hline range & 4.3-5.0 & $42-470$ & $0.4-1.6$ & 83-172 & $86-1,964$ & $28-55$ & 76-369 & $218-2,200$ \\
\hline \multicolumn{9}{|c|}{ Size fraction $<2 \mathrm{~mm}$} \\
\hline Rohtak mean & 4.9 & 375 & 1.3 & 68 & 187 & 32 & 178 & 334 \\
\hline range & 2.8-9.8 & $302-488$ & $0.5-2.1$ & $47-87$ & 108-336 & $26-46$ & $107-277$ & $195-488$ \\
\hline Jind mean & 3.9 & 280 & 4.2 & 46 & 173 & 27 & 125 & 320 \\
\hline range & 3.6-4.2 & $225-368$ & $0.4-11.0$ & $36-54$ & $36-368$ & $22-29$ & $31-176$ & $143-618$ \\
\hline Karnal mean & 4.3 & 345 & 1.1 & 93 & 290 & 32 & 155 & 450 \\
\hline range & $3.3-5.1$ & $228-463$ & $0.4-1.8$ & $45-137$ & $78-596$ & $24-34$ & $40-262$ & $210-772$ \\
\hline
\end{tabular}

Table 6: Average soluble (DTPA extractable) heavy metal concentration (mg kg-1) in Rohtak, Jind and Karnal for the size fraction $<2 \mathrm{~mm}$ and the depths $0-1 \mathrm{~m}$ and $1-2 \mathrm{~m}$

\begin{tabular}{|c|c|c|c|c|c|c|c|c|}
\hline Site & Depth (m) & $\mathrm{Cd}\left(\mathrm{mg} \mathrm{kg}^{-1}\right)$ & Co $\left(\mathrm{mg} \mathrm{kg}^{-1}\right)$ & $\mathrm{Cr}\left(\mathrm{mg} \mathrm{kg}^{-1}\right)$ & $\mathrm{Cu}\left(\mathrm{mg} \mathrm{kg}{ }^{-1}\right)$ & $\mathrm{Ni}\left(\mathrm{mg} \mathrm{kg}{ }^{-1}\right)$ & $\mathrm{Pb}\left(\left(\mathrm{mg} \mathrm{kg}^{-1}\right)\right.$ & $\mathrm{Zn}\left(\mathrm{mg} \mathrm{kg}^{-1}\right)$ \\
\hline \multirow[t]{2}{*}{ Rohtak } & $0-1$ & 0.18 & 0.13 & 0.23 & 10.6 & 1.60 & 11.1 & 9.1 \\
\hline & $1-2$ & 0.31 & 0.15 & 0.26 & 15.6 & 0.77 & 12.7 & 9.6 \\
\hline \multirow[t]{2}{*}{ Jind } & $0-1$ & 0.48 & 0.16 & 0.20 & 13.0 & 0.42 & 8.4 & 8.9 \\
\hline & $1-2$ & 1.37 & 0.18 & 0.25 & 14.1 & 0.55 & 9.9 & 9.9 \\
\hline \multirow[t]{2}{*}{ Karnal } & $0-1$ & 0.16 & 0.20 & 0.24 & 14.4 & 0.98 & 11.7 & 9.3 \\
\hline & $1-2$ & 0.25 & 0.20 & 0.21 & 27.6 & 0.99 & 14.5 & 10.2 \\
\hline
\end{tabular}

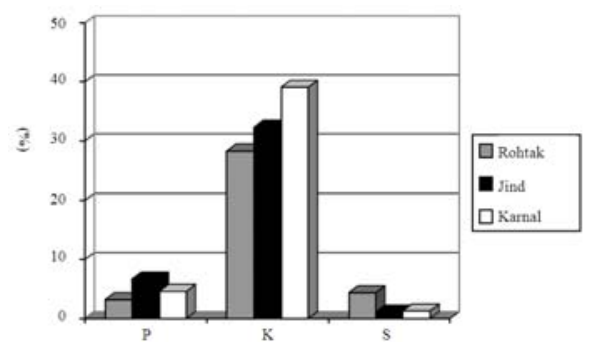

Fig. 5: Percentage of available $\mathrm{P}, \mathrm{K}$ and $\mathrm{S}$ in relation to the total concentrations of $\mathrm{P}, \mathrm{K}$ and $\mathrm{S}(\%)$ in Rohtak, Jind and Karnal

Total phosphorus content in samples of $<2 \mathrm{~mm}$ size fraction was relatively higher in Rohtak site than Jind and Karnal (Table 4). While the total potassium concentration revealed comparable results between the three sites, clear differences for sulfur were discovered. It was interesting to note that the total $S$ content was fairly high and greater than all other nutrients. In general, the results indicated that the wastes are rich sources of potentially available plant nutrients.

For using the waste in agriculture the plant available nutrients are predominantly of interest. As shown in Table 4, the plant available concentrations of $\mathrm{P}, \mathrm{K}$ and $\mathrm{S}$ mostly indicated higher values for Rohtak. If the ratio of the available value and the total amount based on average values is taken into account, available phosphorus has a value of $3.2-6.7 \%$ and sulfur of 1.1 $4.4 \%$ only. The macronutrient potassium, however, even reached a value ranging as high as $28.8-39.1 \%$ (Fig. 5).

Contaminants of the waste samples: The analysis results of samples of city solid waste collected from Rohtak, Jind and Karnal dumping sites showed the presence of metals such as $\mathrm{As}, \mathrm{Ba}, \mathrm{Cd}, \mathrm{Cr}, \mathrm{Cu}, \mathrm{Ni}, \mathrm{Pb}$ and $\mathrm{Zn}$ (Table 5). Based on the total concentration (aqua regia extract) in most cases a significant difference between two size fractions results were not possible to detect. In tendency, some elements revealed higher values in the fraction $>2 \mathrm{~mm}$, e.g., $\mathrm{Cr}, \mathrm{Cu}$ and $\mathrm{Zn}$ in Karnal. Between the three investigated sites some metals did not show clear differences such as As, Ba, $\mathrm{Ni}$ and $\mathrm{Pb}$. Apart, As and $\mathrm{Ni}$ indicated relatively low concentrations in general. With reference to $\mathrm{Cd}$ the Jind site presented enhanced values, while high $\mathrm{Cr}$ and $\mathrm{Zn}$ concentrations were focused on Karnal. Cu amounting of a high level in all sites did not indicate uniform tendencies, but this element reached extreme values in some samples in Karnal (maximum: 1,964 $\mathrm{mg} \mathrm{kg}^{-1}$ ), similar to $\mathrm{Zn}$ that also showed extremely high concentration in some samples in Karnal (maximum: 2,200 $\mathrm{mg} \mathrm{kg}^{-1}$ ).

In both size fractions $>2$ and $<2 \mathrm{~mm}$, the concentration of almost all the DTPA extractable metals was found more in subsurface $(1-2 \mathrm{~m})$ depth compared to surface layer $(0-1 \mathrm{~m})$ depth samples, contrary to the total concentrations (Table 6). 
Am. J. Environ. Sci., 7 (1): 26-34, 2011

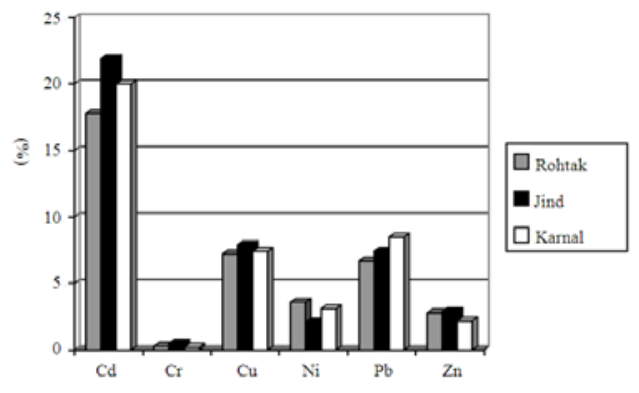

Fig. 6: Percentage of the DTPA extractable metals Cd, $\mathrm{Cr}, \mathrm{Cu}, \mathrm{Ni}, \mathrm{Pb}$ and $\mathrm{Zn}$ in relation to their total (aqua regia) extractable concentration (\%) in Rohtak, Jind and Karnal

Table 7:Average values of heavy metals in tube well waters $\left(\mathrm{mg} \mathrm{L}^{-1}\right)$ collected in the vicinity of Rohtak, Jind and Karnal, dumpsites

\begin{tabular}{lllllll}
\hline \multicolumn{2}{c}{$\begin{array}{l}\mathrm{Cd} \\
\left(\left(\mathrm{mg} \mathrm{L}^{-1}\right)\right.\end{array}$} & $\begin{array}{l}\mathrm{Cu} \\
\left(\mathrm{mg} \mathrm{L}^{-1}\right)\end{array}$ & $\begin{array}{l}\mathrm{Cr} \\
\left(\mathrm{mg} \mathrm{L}^{-1}\right)\end{array}$ & $\begin{array}{l}\mathrm{Ni} \\
\left(\mathrm{mg} \mathrm{L}^{-1}\right)\end{array}$ & $\begin{array}{l}\mathrm{Pb} \\
\left(\mathrm{mg} \mathrm{L}^{-1}\right)\end{array}$ & $\begin{array}{l}\mathrm{Zn} \\
\left(\mathrm{mg} \mathrm{L}^{-1}\right)\end{array}$ \\
\hline Rohtak $(\mathrm{n}=3)$ & 0.27 & nd & nd & 0.07 & 1.02 & 0.09 \\
Jind $(\mathrm{n}=3)$ & 0.22 & nd & nd & 0.06 & 0.02 & 0.15 \\
Karnal $(\mathrm{n}=3)$ & 0.26 & nd & nd & 0.08 & 0.02 & nd \\
\hline
\end{tabular}

Most tendencies of the total extraction solution (e.g., high Cd values for Jind, high $\mathrm{Zn}$ values for Karnal, general high $\mathrm{Cu}$ concentrations) were also found in the DTPA extraction method.

Cadmium is supposed to reveal the highest mobility. A ratio DTPA/aqua regia extraction of 17.8$21.9 \%$ was found for this element, while the results of the other calculated metals were much lower varying between 6.7 and $7.9 \%(\mathrm{Cu}, \mathrm{Pb}), 2.1$ and $3.6 \%(\mathrm{Ni}, \mathrm{Zn})$ and 0.2 and $0.5 \%(\mathrm{Cr})$. Moreover, the three sites of concern showed comparable results (Fig. 6).

Additionally, for the present study subsurface groundwater samples from the tube wells were collected from around the landfill sites of Rohtak, Jind and Karnal. For the determination of heavy metals, the samples have been collected in plastic bottles, which were previously soaked and washed with nitric acid and rinsed with double distilled water. The samples collected from shallow aquifers from Rohtak, Jind and Karnal dumping sites showed high concentrations of $\mathrm{Cd}$. Moreover, the $\mathrm{Pb}$ concentrations in Rohtak were very high, while the other metals $(\mathrm{Cu}, \mathrm{Cr}, \mathrm{Ni}, \mathrm{Zn})$ were generally rather small (Table 7).

Apart from the metals, several organic pollutants were also involved in the dumpsite investigations. Surprisingly low concentrations were detected referring to the Polycyclic Aromatic Hydrocarbons (PAH-EPA). Only one sample reacted positively revealing a value of $0.44 \mathrm{mg} \mathrm{kg} \mathrm{kg}^{-1}$ (in Karnal). In general, PAH and benzo(a)pyrene concentrations fell below the detection limit (0.05 $\mathrm{mg} \mathrm{kg}^{-1}$ for benzo(a)pyrene). In most of the samples also the phenol index did not exceed the detection limit of $1.2 \mathrm{mg} \mathrm{kg}^{-1}$. Exceptionally, one sample of Rohtak (1.4 mg kg${ }^{-1}$ ) and one of Jind (2.9 mg $\mathrm{kg}^{-1}$ ) resulted in detectable values. In 14 out of 36 samples a GC-MS screening was conducted in order to get an overview of the organic pollutants usually present in the dumpsites. In all cases there was no relevant amount of organic pollutants that would be capable of measurement.

\section{DISCUSSION}

The composition of the waste is heterogeneous, but the mineral partition appeared to be dominant, since the TOC values ranged between 3.8 and $5.4 \%$. Thus, the current dumping sites can be classified as sites that consist mainly of non-biodegradable material. The low TOC values are caused by the long-term biodegradation and furthermore by consumption related to animal impact. Organic materials were partly removed, since animals consume the edible percentages. Besides cows, pigs and dogs, the birds use the widespread unplanned heaps of garbage in city areas, leading to an uncontrolled dispersion of the organic waste materials. Normally, the organic matter content in Indian dumpsites indicates values between 34.9 and $47.5 \%$, nitrogen between 0.39 and $0.54 \%$ and the $\mathrm{C} / \mathrm{N}$ ratio exhibited results from 11 till 30 (Rawat et al., 2008). These values correspond more or less to the results presented in Table 3.

Other studies dealing with Indian waste production mentioned $\mathrm{C} / \mathrm{N}$ ratios from $25-40$. The ratios are typical for waste deposits containing ash residues (Meuser, 2010). Other examples of solid waste investigations even resulted in C/ $\mathrm{N}$ ratios up to 950 (Gautam et al., 2009). In fact, it is visually difficult to distinguish ashes from fine earth. In publications given by the Ministry of Non-Conventional Energy Resources of India ashes and fine earth are statistically not separated. The values of the ash-soil-mixture were measured in a number of cities such as Kolkata (34.0\% of the garbage volume), New Delhi (36.0\%) and Mumbai (45.6\%) (MNCES, 1996). Moreover, the high percentage of fine earth resulted from the special situation in Indian cities, where the inhabitants sweep away the waste around their residents on unpaved areas, so that a lot of loose soil material is combined with the waste particles.

There is no doubt that the composition of the dumpsites may continuously change, because manmade influences occur permanently. Rag pickers, for instance, search for valuable material just after 
depositing which surely is in charge with a decrease of metals in the long run. Nevertheless, the finding rates of the considered dumping sites in Haryana in association with the inert materials correspond with results from the MNCES (1996). In the above mentioned cities the percentage of plastics ranged from $0.7-2.0 \%$, of metals from $0.7-3.6 \%$ and of glass from $0.2-0.6 \%$, respectively.

The neutral $\mathrm{pH}$ values analyzed can be explained by the potentially calcareous material such as bricks and mortar. The results agree on other Indian dumpsites in Bangalore, Chennai, Kolkata and Delhi, which indicated $\mathrm{pH}$ values varying from 7.8-8.2 (Rawat et al., 2008).

No definite trend of variation in nutrients content was observed with respect to different waste dumping sites. As expected, all the waste samples contained sufficient amounts of available $\mathrm{P}, \mathrm{K}$ and $\mathrm{S}$ as per the criteria outlined for agricultural soils in India defined as p>20 kg h ${ }^{-1}$ (Olsen, 1954), K>248 kg h ${ }^{-1}$ (Page, 1983) and $\mathrm{S}>40 \mathrm{~kg} \mathrm{~h}^{-1}$ (Chesnin and Yien, 1950), respectively. Taking a specific density of $1.5 \mathrm{~g} \mathrm{~cm}^{-3}$ and a depth of $20 \mathrm{~cm}$ into account the values for available P should exceed $6.6 \mathrm{mg} \mathrm{kg}^{-1}$ and for available $\mathrm{K} 82 \mathrm{mg} \mathrm{kg}^{-1}$. Accordingly, the measured nutrient concentrations of the waste samples reveal extremely higher values than the criteria defined for agricultural soils. Household waste deposits, however, result in densities of about $0.5 \mathrm{~g} \mathrm{~cm}^{-3}$ only (Meuser, 2010), so that the nutrient criteria have to be multiplied by three leading to values of $19.8 \mathrm{mg} \mathrm{kg}^{-1}$ for $\mathrm{P}, 246 \mathrm{mg} \mathrm{kg}^{-1}$ for $\mathrm{K}$ and $120 \mathrm{mg} \mathrm{kg}^{-1}$ for S, respectively. Nevertheless, the waste samples indicate a high nutrient supply in any case. These results exceeded intensively the longtermed used garden soils which were fertilized with household waste, e.g., in Nanjing (China), where the available $\mathrm{P}$ content ranged between 40 and $110 \mathrm{mg} \mathrm{kg}^{-1}$ (Zhang et al., 2001).

Compared with the nutrient assessment mapped out for anthropogenic soils in urban environments (Meuser, 2010) the total P content is assessed as being very high, if the value exceeds $0.15 \%$. Analogous values (very high) are for plant available $\mathrm{p}>157 \mathrm{mg} \mathrm{kg}^{-1}$ and for plant available potassium $>183 \mathrm{mg} \mathrm{kg}^{-1}$. With respect to the total $\mathrm{P}$ content $(0.25-1.09 \%)$ the results corresponded to the analyses of Indian composts amounting $0.1-0.8 \%$ P. The published values for $\mathrm{K}$ $(0.1-2.0 \%)$ are of similar magnitude like the measurements in Haryana (0.43-1.09\%) and the analyzed S values $(0.3-4.7 \%)$ are in the order of the compost results (0.5-3.0\%) (World Health Organization, 1985). European municipal solid waste composts are also rich in macronutrients as values of $0.23-0.32 \%$ (total P) and $0.30-0.87 \%$ (total $\mathrm{K}$ ) were observed (Umweltbundesamt, 2001).

Therefore, it can be concluded that the dumping sites are nutrient storage places that should not be underestimated in future in a line with ideas of urban mining. Particularly, the potassium source for soil fertilization based on treated waste material could be of relevance, because this element showed high plant availability. The possibility of using the waste material for fertilizing purposes may mainly be restricted to the contaminant concentrations expected. It has been reported that samples from large landfill sites in different European countries indicated high contaminant heterogeneity. Most of the parameters involved revealed higher concentrations in household landfills than in landfills consisting predominantly of inert construction debris. It should be noted that the concentrations changed with time depending on the stage of decomposition (residual accumulation of metals). With reference to the total metal concentration the arsenic content agreed on the measurements resulting from waste deposit investigations in different European, Asian and American studies (1.8-10.0 mg $\mathrm{kg}^{-1}$ ). Same tendencies were possible to observe for the elements chromium (40-200 $\mathrm{mg} \mathrm{kg}^{-1}$ ) and nickel (30-50 $\mathrm{mg} \mathrm{kg}^{-1}$ ) (Williams, 2005).

On contrary, the cadmium values of the Indian dumpsites fell partly below the reported concentration of $1-150 \mathrm{mg} \mathrm{kg}^{-1}$. However, the results from Jind appeared to indicate an enhanced level, e.g., in comparison with dumpsite analyses in Leeds, United Kingdom (0.4-1.8 mg kg-1). The variation for copper (200-700 mg kg-1), lead (100-2,000 $\mathrm{mg} \mathrm{kg}^{-1}$ ) and zinc (400-1,400 mg kg-1) stemming from the investigations mentioned showed comparable tendencies, some values of the Karnal analyses, however, revealed extremely high $\mathrm{Cu}$ and $\mathrm{Zn}$ concentrations. Looking at the investigation in Leeds the measured values in the Indian dumpsites were much higher with respect to copper (41-100, with a mean value of $64 \mathrm{mg} \mathrm{kg}^{-1}$ ), lead (33247, mean value $101 \mathrm{mg} \mathrm{kg}^{-1}$ ) and zinc (149-313, mean value $226 \mathrm{mg} \mathrm{kg}^{-1}$ ) (Williams, 2005). A possible reason is the room heating and cooking in poorer localities, where different materials are burnt in portable steel stoves. Residues of at least $15-20 \%$ are left as small pieces of coal and ash and in India it is an easy and common method to dispose of this material on unpaved areas close to the site of origin.

On the other hand, the elevated values of $\mathrm{Cu}, \mathrm{Pb}$ and Zn, particularly found in Karnal, should be considered exceptionally, since most of the values in Rohtak and Jind are compatible with dumpsite analyses 
generally published. Similarly, results from solid waste compost material in Kolkata indicated lower values, e.g., $60-300 \mathrm{mg} \mathrm{kg}-1$ for $\mathrm{Cu}, 100-200$ for $\mathrm{Pb} \mathrm{mg} \mathrm{kg}{ }^{-1}$ and 200-900 mg kg-1 for Zn (Hoitink, 1993). In addition, it should be mentioned that the distinct dumpsites and composting facilities might demonstrate a wide range of metal values depending on the industrial influence in the vicinity of the specific location. For instance, a singular investigation of a compost pile in Panipat (in the same State of Haryana) revealed moderate $\mathrm{Cu}$ (37-149 $\mathrm{mg} \mathrm{kg}^{-1}$ ), $\mathrm{Pb}$ (13-67 mg $\mathrm{kg}^{-1}$ ) and $\mathrm{Zn}$ (82-168 $\mathrm{mg} \mathrm{kg}^{-1}$ ) concentrations, but problematical Ni (225-337 $\mathrm{mg} \mathrm{kg}^{-1}$ ) and $\mathrm{Cr}$ (411-647 $\mathrm{mg} \mathrm{kg}^{-1}$ ) values that can be associated with specific industry branches (e.g., dyeing manufactories) nearby. Apart, the phenol index of this pile ranged between 2.0 and $4.2 \mathrm{mg} \mathrm{kg}^{-1}$.

, There are no governmental threshold values for assessment purposes in India. The Municipal Solid Waste (Management and Handling) Rules (2000) did not include quality standards. For this reason, the permissible and toxic limits respectively given by Chapman (1966) and Soler-Rovira et al. (1996), as used by several other workers in India were followed for interpretation. The mean potentially available metal content detected by DTPA extraction exceeded the permissible critical limits for cadmium $(0.5 \mathrm{mg}$ $\mathrm{kg}^{-1}$ ) in a number of samples. Contrary to that, the upper critical limits of $\mathrm{Cr}\left(10 \mathrm{mg} \mathrm{kg}^{-1}\right), \mathrm{Cu}(5 / 30 \mathrm{mg}$ $\mathrm{kg}^{-1}$ ), Ni (50 mg kg$\left.{ }^{-1}\right), \mathrm{Pb}\left(20 \mathrm{mg} \mathrm{kg}^{-1}\right.$ ) and $\mathrm{Zn}$ $\left(150 / 200 \mathrm{mg} \mathrm{kg}^{-1}\right)$ did not seem to be problematical.

The high mobility of $\mathrm{Cd}$ could be confirmed by the ratio of DTPA/aqua regia extraction. Up to approx. $22 \%$ of the total concentration was calculationally available. The lower percentages of e.g., $\mathrm{Pb}$ and $\mathrm{Zn}$ are linked to the neutral $\mathrm{pH}$ value analyzed, since the mobility is expected to increase at $\mathrm{pH}$ values below 6.0 (Zn) and $5.0(\mathrm{~Pb})$ (Brümmer et al., 1986). Accordingly, the rest of the toxic metals contents were still below their permissible limit. Leachate from household waste dumps usually contain between 0.01 and $0.10 \mathrm{mg} \mathrm{L}^{-1}$ Cd (Williams, 2005), in this study all sites exceeded this level. For $\mathrm{Pb}$, values ranging from $0.04-1.90 \mathrm{mg}$ $\mathrm{L}^{-1}$ were recorded and in Rohtak a comparably enhanced concentration was found. On the contrary, the detected results referring to $\mathrm{Cu}, \mathrm{Ni}$ and $\mathrm{Zn}$ can be considered as relatively low in comparison to the mentioned research studies published in Williams (2005). The oriented analyses of the tube well samples underline the elevated $\mathrm{Cd}($ and $\mathrm{Pb}$ ) mobility leading to considerable downward percolation of the metals.

The dumping grounds were mainly open low-lying areas in or next to the cities. The waste was generally dumped without any segregation into biodegradable and non-biodegradable parts. The municipal solid waste came from domestic, agricultural and commercial sources and there was also construction rubble. Especially in Jind, it cannot be excluded that medical waste from the adjacent hospital was dumped simultaneously to the household waste.

However, the analyzed organic pollutants did not indicate problematical concentrations. Apart from an only negligible portion of hazardous wastes, biodegradation is possible to reduce the concentrations considerably. The higher temperature characteristic of the Indian climate resulted in a higher rate of biodegradation and odor development of reductive gases. Especially (the odorless) methane is produced continuously in large quantities independent of the landfill management. Even after the waste was buried at the sites methane generation might take place permanently. The neutral $\mathrm{pH}$ value of the waste that has been analyzed improved the methanogenesis. Thus, in Indian dumpsites $\mathrm{CH} 4$ generated ranged from 146-454 $\mathrm{mg} \mathrm{m}^{-2} \mathrm{~h}^{-1}$. By comparison in Swedish dumpsites (humid, continental climate) the range was $0.5-320 \mathrm{mg}$ $\mathrm{m}^{-2} \mathrm{~h}^{-1}$ (Rawat et al., 2008). The methane generation might be a good indication of the high biodegradation rate probably transferable to organic pollutants as well.

\section{CONCLUSION}

The analyzed waste samples indicate high plant nutrient content. Therefore, the dumping sites are plant nutrient deposits, particularly for $\mathrm{K}$, which showed high plant availability. The deposits could be used in future in a line with ideas of urban mining. The metal concentrations were on a similar level as reported from other European or Asian studies. Because the composition of the dumpsites may continuously change due to man-made influences, the use of the waste material for fertilizing purposes may be restricted mainly due to the toxic heavy metal concentrations. The analyzed organic pollutants did not indicate problematical concentrations. Using the dumping sites as source of plant nutrient requires monitoring, especially of the metal concentrations.

\section{REFERENCES}

Brümmer, G.W., J. Gerth and U. Herms, 1986. Heavy metal species, mobility and availability in soils. Plant Nutrition Soil Sci., 149: 382-396. DOI: 10.1002/jpln.19861490404

World Health Organization, 1985. Solid Waste Management: Selected Topics. 1st Edn., World Health Organization, Regional Office for Europe, Switzerland, ISBN: 9289010231, pp: 210. 
Am. J. Environ. Sci., 7 (1): 26-34, 2011

Chapman, H.D., 1966. Diagnostic Criteria for Plants and Soils. 1st Edn., University of California, Div. of Agricultural Sciences,,USA., pp: 793.

Chesnin, L. and C.H. Yien, 1950. Turbidimetric determination of available sulphur. Soil Sci. Soc. Am. Proc., 15: 149-151. http://www.nrccnrc.gc.ca/obj/irc/doc/pubs/ir/ir370/ir370.pdf

Gautam, S.P, P.S. Bundela, A.K. Pandey, R.K. Jain and P.R. Deo et al., 2009. Biodegradation and Recycling of urban solid waste. Am. J. Environ. Sci., 5: 653-656. DOI: 10.3844/ajessp.2009.653.656

Hoitink, H.A.J., 1993. Science and Engineering of Composting: Design, Environmental, Microbiological and Utilization Aspects. 1st Edn., Ohio State University, USA., ISBN-10: 0936645156, pp: 728.

Koenig, R.A. and C.R. Johnson, 1942. Colorimetric determination of $\mathrm{P}$ in biological materials. Ind. Eng. Chem. Anal. Ed., 14: 155-156. DOI: 10.1021/i560102a026

Lindsay, W.L. and W.A. Norvell, 1978. Development of a DTPA soil test for zinc, iron, manganese and copper. Soil Sci. Society Am. J., 42: 421-428.

Hein, D., 1994. Bestimmung von Polyzyklischen Aromatischen Kohlenwasserstoffen (PAK) in Bodenproben. 1st Edn., Landesumweltamt Nordrhein-Westfalen, pp: 21.

Meuser, H., 2010. Contaminated urban soils. 1st Edn., Springer Verlag, UK., ISBN-10: 9048193273, pp: 318.

MNCES, 1996. Ministry of Non-Conventional Energy Sources. Indian Institute of Technology.

The Municipal Solid Waste (Management and Handling) Rules, 2000. Ministry of Environment and Forests. Government of India.

Olsen, S.R., 1954. Estimation of Available Phosphorus In Soils By Extraction With Sodium Bicarbonate. 1st Edn., U.S. Department of Agriculture, USA., pp: 19.
Piper, C.S., 1966. Soil and Plant Analysis: A Laboratory Manual of Methods for the Examination of Soils and the Determination of the Inorganic Constituents of Plants. 1st Edn., Hans Publications, Bombay, pp: 368.

Page, A.L. 1983. Methods of Soil Analysis, Part II Chemical and Microbiology Properties. 2nd Edn., Amer Society of Agronomy, USA., ISBN-10: 0891180729

Rawat, M., U.K. Singh, A.K. Mishra and V. Subramanian, 2008. Methane emission and heavy metals quantification from selected landfill areas in India. Environ. Monitoring Assess., 137: 67-74. DOI: 10.1007/s10661-007-9729-8

Soler-Rovira, P., J. Soler-Soler, J. Soler-Rovira and A. Polo, 1996. Agricultural use of sewage sludge and its regulation. Nutrient Cycl. Agroecosys., 43: 173-177. DOI: $10.1007 / \mathrm{BF} 00747698$

Umweltbundesamt, 2001. Daten zur Umwelt 2000.: Der Zustand der Umwelt in Deutschland. 7th Edn., Schmidt, USA., ISBN-10: 3503059733, pp: 380.

Walkley, A. and I.A. Black, 1934. An examination of the degjareff method for determining SOM and a proposed modification of the chromic acid titration method. Soil Sci. 37:29-38.

Williams, P.T., 2005. Waste Treatment and Disposal. 2nd Edn., John Wiley and Sons, Chichester, ISBN10: 0470849126, pp: 380.

Zhang, G.L., W. Burghardt, Y. Lu and Z.T. Gong, 2001. Phosphorus-enriched soils of urban and suburban Nanjing and their effect on groundwater phosphorus. J. Plant Nutrition Soil Sci., 164: 295-301. DOI: $10.1002 / 1522-$

2624(200106)164:3<295::AID-

JPLN295>3.0.CO;2-T 